\title{
PEMBERIAN ASI EKSKLUSIF DAN STATUS GIZI SERTA HUBUNGANYA TERHADAP KEJADIAN DIARE PADA BALITA DI WILAYAH KERJA PUSKESMAS JUNTINYUAT
}

\author{
Ade Rahmawati \\ Universitas Wiralodra, Jl. Ir. H. Juanda KM. 03 Karanganya Indramayu, \\ aderahmawati@unwir.ac.id
}

Diterima 18 Januari 2019, disetuji 22 Februari 2019, diterbitkan 30 April 2019

Pengutipan:Rahmwatii, A. (2019). Pemberian ASI Eksklusif dan Status Gizi Serta Hubunganya Terhadap Kejadian Diare pada Balita di Wilayah Kerja Puskesmas Juntinyuat. Gema Wiralodra, Vol 10, No 1, Hal 105-114, April 2019

\begin{abstract}
ABSTRAK
Diare adalah peningkatan jumlah buang air besar ( 3 kali atau lebih) disertai dengan perubahan konsistensi tinja (menjadi lebih encer atau berair) dalam waktu 24 jam. Penyakit diare saat ini masih merupakan masalah global dan banyak terjangkit di negara-negara berkembang dengan kondisi sanitasi lingkungan yang buruk, tidak cukup pasokan air bersih, kemiskinan, dan pendidikan yang rendah. Insiden diare bervariasi di setiap daerah di setiap wilayah, musim, dan masa-masa endemik.Tujuan penelitian ini adalah untuk mengetahui hubungan antara pemberian ASI eksklusif dan status gizi dengan kejadian diare pada balita di wilayah kerja Puskesmas Juntinyuat. Jenis penelitian ini observasional analitik dengan menggunakan desain studi Cross sectional. Populasi pada penelitian ini adalah seluruh balita umur 12-59 bulan yang berada di Wilayah kerja Puskesmas Juntinyuat sebanyak 270 balita yang memili KMS. Sampel dalam penelitian ini adalah balita umur 12-59 bulan yang terpilih sebagai sampel di Wilayah kerja Puskesmas Juntinyuat sebanyak 69 balita. Cara pengambilan sampel dengan Simple Random Sampling. Berdasarkan hasil uji statistik diperoleh nilai analisis bivariat yaitu pemberian ASI eksklusif ( $\mathrm{p}$ value $=0,001$ ) dan status gizi $(\mathrm{p}$ value $=0,002)$ berhubungan dengan kejadian diare pada balita di wilayah kerja Puskesmas Juntinyuat. Diharapkan ibu yang memiliki balita hendaknya selalu memberikan ASI secara eksklusif dan menjaga status gizi balita untuk mencegah terjadinya penyakit diare.
\end{abstract}

Kata Kunci : ASI eksklusif, Status gizi, Diare

\section{ABSTRACT}

Diarrhea is an increase in the number of bowel movements (3 times or more) accompanied by changes in the consistency of stool (becoming more watery or runny) within 24 hours.Diarrhea is still a global problem and many are infected in developing countries with poor environmental sanitation conditions, insufficient water supply, poverty, and low education.The incidence of diarrhea varies in each region in each region, season, and endemic periods. The purpose of this study was to determine the relationship between exclusive breastfeeding and nutritional status with the incidence of diarrhea in infants in the work area of Juntinyuat Health Center. This type of research was observational analytic using a cross sectional study design. The population in this study was all toddlers aged 12-59 months who were in the working area of the Juntinyuat Health Center as many as 270 toddlers who had cards to health. The sample in this study was toddlers aged 12-59 months who were selected as samples in the working area of Juntinyuat Health Center as many as 69 children. How to take samples with Simple Random Sampling. Based on the results of statistical tests obtained the value of bivariate analysis, namely exclusive breastfeeding ( $p$ value $=0.001)$ and nutritional status ( $\mathrm{p}$ value $=0.002)$ related to the incidence of diarrhea in infants in the work area of Juntinyuat Health Center.It is expected that mothers who have toddlers should always give exclusively and maintain the nutritional status of children to prevent the occurrence of diarrheal diseases.

Keywords: Exclusive breastfeeding, Nutritional status, diarrhea 


\section{PENDAHULUAN}

Penyakit diare saat ini masih merupakan masalah global dan banyak terjangkit di negara-negara berkembang dengan kondisi sanitasi lingkungan yang buruk, tidak cukup pasokan air bersih, kemiskinan, dan pendidikan yang rendah. Insiden diare bervariasi di setiap daerah di setiap wilayah, musim, dan masa-masa endemik.Gangguan kesehatan pada masa balita dapat mempengaruhi tumbuh kembang, khususnya gangguan pada saluran pencernaan seperti diare. Diare mempengaruhi proses penyerapan nutrisi untuk perkembangan balita (Kementerian Kesehatan RI, 2011) dan diare merupakan penyebab utama kematian balita secara global (Pahwa, 2010).

Menurut data (WHO, 2013), diare merupakan penyakit yang berbasis lingkungan dan terjadi hampir di seluruh daerah geografis di dunia. Setiap tahunnya ada sekitar 1,7 miliar kasus diare dengan angka kematian 760.000 anak di bawah 5 tahun. Pada negara berkembang, anak-anak usia di bawah 3 tahun rata-rata mengalami 3 episode diare pertahun. Setiap episodenya, diare akan menyebabkan kehilangan nutrisi yang dibutuhkan anak untuk tumbuh, sehingga diare merupakan penyebab utama malnutrisi pada anak dan menjadi pada tahun 2010 dilaporkan 2,5 juta kasus diare pada anak diseluruh dunia. Kasus diare terbanyak di Asia dan Afrika kurang memadainya status gizi pada anak dan kurangnya sanitasi air bersih (Riskesdas, 2013).

Berdasarkan data United Nation Children's Fund (UNICEF) dan World Health Organization (WHO) (World Health Organization, 2013), secara global terdapat dua juta anak meninggal dunia setiap tahunnya karena diare. Jumlah penderita Kejadian Luar Biasa (KLB) diare tahun 2013 di Indonesia menurun secara signifikan dibandingkan tahun 2012 dari 1.654 kasus menjadi 646 kasus pada tahun 2013.

Menurut data yang dihimpun dari Kementrian Kesehatan Republik Indonesia pada tahun 2017 menyatakan bahwa di Provinsi Jawa Timur memiliki angka kejadian diare tertinggi kedua setelah Jawa Barat yang mencapai angka 1.048.885 penderita, dan disusul oleh Jawa Tengah dengan angka kejadian 911.901 penderita (Budijanto, 2017). Pada laporan Puskesmas Juntinyuat menunjukkan bahwa jumlah kasus diare pada tahun 2017 sebanyak 224 selama bulan agustus 2017 sampai bulan oktober 2017.

Berbagai penelitian tentang diare akut pada anak balita telah dilakukan sebelumnya dan menjelaskan bahwa faktor yang mempengaruhi diare akut pada anak balita tidak hanya berdiri sendiri, akan tetapi saling terkait dan sangat kompleks. ${ }^{10}$ Banyak faktor yang diduga menjadi penyebab diare akut pada anak balita, diantaranya adalah berat badan lahir, status 
gizi, status imunisasi campak, riwayat pemberian zinc, pola pemberian ASI, pengetahuan ibu, kebiasaan mencuci tangan ibu dan faktor lingkungan seperti keberadaan tempat sampah dan sarana pembuangan air limbah rumah tangga.

Penelitian yang dilakukan oleh Limberti dkk (2011) dengan systematic review yang mengambil literature dari tahun 1980 sampai tahun 2009 membuktikan adanya hubungan kejadian diare dengan pola pemberian ASI. Penelitian tersebut menjelaskan bahwa risiko kejadian diare pada balita meningkat sesuai dengan pola pemberian ASI. Hal ini ditunjukan dengan Relative Risk (RR) pada kelompok ASI predominan sebesar 1,26, kelompok ASI parsial sebesar 1,68 dan pada kelompok non ASI sebesar 2,65. Risiko diare yang dilihat dari angka prevalensi juga meningkat secara bermakna menurut polapemberian ASI. Pada kelompok ASI predominan $(\mathrm{RR}=2,15)$ pada kelompok ASI parsial $(\mathrm{RR}=4,62)$ dan pada kelompok non ASI $(\mathrm{RR}=4,90)$ dibandingkan dengan kelompok ASI eksklusif.

Kejadian diare akut juga berkaitan dengan status gizi anak (Mutia, 2012). Hal ini didukung dengan penelitian yang dilakukannya di Depok dengan sampel 95 orang bahwa status gizi berhubungan dengan kejadian diare (status gizi $\mathrm{BB} / \mathrm{U}$ dengan $\mathrm{OR}=8,3$ ) dan $\mathrm{PB} / \mathrm{U}$ dengan $\mathrm{OR}=14,8$ ). Penelitian lain yang dilakukan oleh Fitriyani tahun 2005 di Palembang menunjukan hubungan yang signifikan antara status gizi dan kejadian diare. Selain itu penelitian yang dilakukan olehDewi tahun 2011 di Bali menunjukan hubungan yang signifikan antara status gizi dengan kejadian diare (OR=5,46, 95\% CI: 3,03-9,84). Demikian halnya penelitian yang dilakukan oleh Checkley (2001) menunjukan hubungan antara status gizi dengan frekuensi diare pada bayi. Hasil penelitian tersebut menunjukan frekuensi diare meningkat setiap penurunan $15 \% \mathrm{z}$ score berdasarkan TB/U. Hasil Riskesdas secara serial menggambarkan nilai fluktuatif terkait angka kejadian malnutrisi di Indonesia. Angka kejadian gizi kurang berdasarkan indeks berat badan terhadap umur pada balita mencapai 18,4\% (Rikesdas, 2007); 17,9\% hasil Riskesdas 2010 dan 19,6\% hasil Riskesdas 2013. Angka kejadian gizi buruk pada balita mencapai 5,4\% (Riskesdas, 2013).

Upaya pencegahan dan penanggulangan diare yang dilakukan oleh pemerintah antara lain adalah telah menetapkan kebijakan tatalaksana penderita diare yang sesuai standar, baik di sarana kesehatan maupun dirumah tangga, melaksanakan surveilans epidemiologi dan Sistem Kewaspadaan Dini Kejadian Luar Biasa (SKD-KLB), meningkatkan pengetahuan dan keterampilan petugas dalam pengelolaan program yang meliputi aspek manajerial dan teknis medis, melaksanakan evaluasi sebagai dasar perencanaan selanjutnya. Kebijakan tersebut ditetapkan dalam rangka menurunkan angka 
kesakitan dan kematian akibat diare. Meskipun demikian, penyakit diare masih menjadi masalah kesehatan masyarakat dan angka kesakitan diare masih cukup tinggi sampai sekarang ini (Kemenkes RI, 2011).Berdasarkan permasalahan dan data yang telah dipaparkan tersebut, peneliti perlu melakukan penelitian untuk mengetahui hubungan antara pemberian ASI eksklusif dan status gizi dengan kejadian diare pada balita di wilayah kerja Puskesmas Juntinyuat.

\section{METODE PENELITIAN}

Jenis penelitian ini adalah observasional analitik dengan menggunakan desain studi Cross Sectional. Teknik pengambilan sampel menggunakanSimple Random Sampling. Populasi dalam penelitian adalah seluruh balita umur 12-59 bulan yang berada di wilayah kerja Puskesmas Juntinyuat Kabupaten Indramayu sebanyak 270 balita yang memili KMS. Sampel dalam penelitian ini adalah balita umur 12-59 bulan yang terpilih sebagai sampel di wilayah kerja Puskesmas Juntinyuat Kabupaten Indramayu tahun 2017 sebanyak 69 balita.

Teknik pengambilan sampel yang digunakan adalah simple random samplingdengan jumlah sampel sebanyak 69 balita. Data yang diperoleh di uji menggunakan Chisquare(x2) dengan nilai keyakinan 95\% dan tingkat kemaknaan (alfa) 0,05.Penelitian dilakukan di Puskesmas Juntinyuat Kabupaten Indramayu Provinsi Jawa Barat. Pengumpulan data dilakukan pada bulan Agustus-September tahu 2018.Sumber data penelitian diperoleh melalui data primer dan sekunder. Instrumen pengumpulan data primer menggunakan kuesioner sebagai panduan proses wawancara yang sebelumnya responden telah diberi penjelasan dan telah menandatangani pernyataan persetujuan mengikuti penelitian. Variabel dependen penelitian adalah pemberian ASI eksklusif dan status gizi.

\section{HASIL PENELITIAN DAN PEMBAHASAN}

\section{Hasil Penelitian}

a. Analisa Univariat

1) Pemberian ASI Eksklusif

Distribusi responden menurut pemberian ASI eksklusif terdiri diberikan dan tidak diberikan. 
Tabel 1 Distribusi Responden Menurut Pemberian ASI Eksklusif di Wilayah Kerja Puskesmas Juntinyuat

\begin{tabular}{lcc}
\hline $\begin{array}{l}\text { Pemberian ASI } \\
\text { Eksklusif }\end{array}$ & Frekuensi & Persentase (\%) \\
\hline Diberikan & 32 & $46,4 \%$ \\
Tidak diberikan & 37 & $53,6 \%$ \\
Jumlah & 69 & $100 \%$ \\
\hline
\end{tabular}

Data pada tabel 1 menunjukkan bahwa pemberian ASI eksklusif tertinggi adalah balita yang tidak diberikan ASI eksklusif sebanyak 53,6 balita $(53,6 \%)$, dan terendah adalah yang diberikan ASI eksklusif sebanyak 32 orang $(46,4 \%)$.

2) Status Gizi

Distribusi responden menurut status giziterdiri atas baik dan tidak baik.

Tabel 2 Distribusi Responden Menurut Status Gizi di Wilayah Kerja Puskesmas Juntinyuat

\begin{tabular}{lcc}
\hline Status Gizi & Frekuensi & Persentase (\%) \\
\hline Baik & 48 & $69,6 \%$ \\
Tidak Baik & 21 & $30,4 \%$ \\
Jumlah & 69 & $100 \%$ \\
\hline
\end{tabular}

Data pada tabel 2 menunjukkan bahwa status gizi pada balita tertinggi adalah yang memiliki status gizi baik sebanyak 48 orang $(69,6 \%)$, dan yang terendah adalah yang memiliki status gizi tidak baik sebanyak 21 orang $(30,4 \%)$.

b. Analisa Bivariat

1) Hubungan Pemberian ASI Eksklusifdengan Kejadian Diare pada Balita

Untuk mengetahui hubungan pemberian ASI eksklusif dengan kejadian diare pada balita dapat dilihat pada tabel 3:

Tabel 3 Hubungan Pemberian ASI Eksklusif dengan Kejadian Diare pada Balita di Wilayah Kerja Puskesmas Juntinyuat

\begin{tabular}{|c|c|c|c|c|c|}
\hline \multirow{2}{*}{ No } & \multirow{2}{*}{$\begin{array}{c}\text { Pemberian } \\
\text { ASI } \\
\text { Eksklusif }\end{array}$} & \multicolumn{2}{|c|}{ Diare } & \multirow[b]{2}{*}{ Total } & \multirow{2}{*}{$\rho$ value } \\
\hline & & Diare & Tidak Diare & & \\
\hline & Tidak & 23 & 14 & 37 & \multirow{4}{*}{0,001} \\
\hline & Diberikan & $62,2 \%$ & $37,8 \%$ & $100 \%$ & \\
\hline & Diberikan & $\begin{array}{c}7 \\
21,9 \%\end{array}$ & $\begin{array}{c}25 \\
78,1 \%\end{array}$ & $\begin{array}{c}32 \\
100 \%\end{array}$ & \\
\hline & Total & $\begin{array}{c}30 \\
43,5 \% \\
\end{array}$ & $\begin{array}{c}39 \\
56,5 \% \\
\end{array}$ & $\begin{array}{c}69 \\
100 \% \\
\end{array}$ & \\
\hline
\end{tabular}


Berdasarkan Tabel 3 diatas bahwa hasil uji chi-squaredidapatkan nilai $\rho$ value= 0,001 sehingga $\rho$ value $<0,05$ maka Ho pada penelitian ini ditolak artinya, bahwa ada hubungan antara pemberian ASI eksklusif dengan kejadian diare pada balita di wilayah kerja Puskesmas Juntinyuat.

2) Hubungan Status Gizi dengan Kejadian Diare pada Balita

Untuk mengetahui hubungan pola pemberian ASI dengan kejadian ISPA pada balita dapat dilihat pada tabel 4:

Tabel 4 Hubungan Status Gizi dengan Kejadian Diare pada Balita di Wilayah Kerja Puskesmas Juntinyuat

\begin{tabular}{|c|c|c|c|c|c|}
\hline \multirow{2}{*}{ No } & \multirow{2}{*}{ Status Gizi } & \multicolumn{2}{|c|}{ Diare } & \multirow[b]{2}{*}{ Total } & \multirow{2}{*}{$\rho$ value } \\
\hline & & Diare & Tidak Diare & & \\
\hline & Tidak Baik & $\begin{array}{c}15 \\
714 \%\end{array}$ & $\begin{array}{c}6 \\
286 \%\end{array}$ & $\begin{array}{c}21 \\
100 \%\end{array}$ & \multirow{3}{*}{0,002} \\
\hline & Baik & $\begin{array}{c}115 \\
31,3 \%\end{array}$ & $\begin{array}{c}28,0 \% \\
33 \\
68,8 \%\end{array}$ & $\begin{array}{c}100 \% \\
48 \\
100 \%\end{array}$ & \\
\hline & Total & $\begin{array}{r}30 \\
43,5 \% \\
\end{array}$ & $\begin{array}{c}39 \\
56,5 \% \\
\end{array}$ & $\begin{array}{c}69 \\
100 \%\end{array}$ & \\
\hline
\end{tabular}

Berdasarkan Tabel 4 diatas bahwa hasil uji chi-square didapatkan nilai $\rho$ value= 0,002 sehingga $\rho$ value $<0,05$ maka Ho pada penelitian ini ditolak artinya, bahwa ada hubungan antara status gizi dengan kejadian diare pada balita di wilayah kerja Puskesmas Juntinyuat.

\section{Pembahasan}

a. Hubungan Pemberian ASI Eksklusif dengan Kejadian Diare pada Balita

Dalam menit-menit pertama setelah lahir, bayi menunjukkan kemampuan yang menakjubkan.Ketika bayi diletakkan di atas perut/dada ibunya, perlahan bayi dapat merangkak ke arah puting susu ibu dan menyusu sendiri. Proses yang dikenal dengan Inisiasi Menyusu Dini (IMD) tersebut memberikan banyak manfaat. Tidak hanya untuk mempererat ikatan kasih sayang antara ibu dan bayi, IMD dapat meningkatkan keberhasilan pemberian ASI Eksklusif dan menurunkan angka kematian bayi (Roesli, 2008).

Teori yang disampaikan oleh Suhardjo (1992) bahwa pola pemberian ASI merupakan kebiasaan ibu menyusui berdasarkan banyaknya seorang ibu menyusui anaknya. Menyusui merupakan suatu proses alamiah yang sangat diperlukan oleh seorang anak karena air susu ibu merupakan cairan hidup yang mengandung zat protektif guna meningkatkan kekebalan tubuh yang akan melindungi anak dari berbagai infeksi bakteri, 
virus, parasit, dan jamur. Sehingga anak yang disusui oleh ibunya secara penuh selama enam bulan (Pola ASI Eksklusif) lebih sehat dan lebih jarang sakit dibanding dengan anak yang tidak mendapat ASI eksklusif (Suhardjo, 1992).

Hasil uji statistik menunjukan ada hubungan antara pemberian ASI eksklusifdengan kejadian diare pada balita di wilayah kerja Puskesmas Juntinyuat, dengan nilai $\rho$ value= 0,001atau nilai $\rho$ value $<0,05$. Hal ini berarti pemberian ASI eksklusif berhubungan dengankejadian diare pada balita.

Penelitian ini sejalan dengan penelitian Limberti dkk (2011) yang menjelaskan bahwa adanya pengaruh pola menyusui terhadap kejadian diare. Penelitian yang dilakukan oleh Henny (2014) di Medan dengan jumlah sampel 105 balita bahwa pemberian ASI Ekslusif berpengaruh terhadap kejadian diare dengan nilai $\mathrm{p}=0,001$ dan $\mathrm{OR}=11,27$. Penelitian yang dilakukan oleh Yurillah (2010) di Cilegon dengan jumlah sampel 106 bahwa balita yang tidak diberi ASI Eksklusif berpengaruh terhadap kejadian diare dengan nilai $\mathrm{p}=0,000$ dan $\mathrm{OR}=13,588$. Penelitian yang dilakukan oleh Arifeen (2001) di kota Dhaka Bangladeshmenunjukan bahwa bayi yang tidak menyusui ASi Eksklusif (ASI Parsial dan tidak ASI) berpengaruh terhadap kematian akibat diare dengan risiko 3,94 kali.

Hasil ini juga sesuai dengan penelitian yang dilakukan oleh Wijayanti (2010) yang menunjukkan hasil yang signifikan antara presentase kejadian diare yang diberikan ASI Eksklusif dengan yang tidak diberikan ASI Eksklusif dengan nilai signifikan $\mathrm{P}<0,05$ yaitu 0,000 .

ASI bersifat steril dan berbeda dangan susu formula atau cairan lain yang disiapkan dengan air atau bahan-bahan yang dapat terkontaminasi dalam botol yang tidak bersih. Pemberian ASI saja, tanpa cairan atau makanan lain dan tanpa menggunakan botol, menghindarkan anak dari bahaya bakteri dan organisme lain yang akan menyebabkan penyakit diare (Kemenkes RI, 2014).

b. Hubungan Status Gizi dengan Kejadian Diare pada Balita

Status gizi adalah keadaan tubuh yang merupakan hasil akhir dari keseimbangan antara zat gizi yang masuk kedalam tubuh dan juga perwujudan manfaatnya (Gibson, 2005).Teori yang disampaikan oleh Almatseir (2005) bahwa status gizi kurang terjadi bila tubuh mengalami kekurangan satu atau lebih zat-zat eseansial yang dapat menghambat pertumbuhan fisik, perkembangan mental dan kecerdasan. Disamping itu, anak balita yang mengalami gizi kurang memiliki daya tubuh yang menurun sehingga sangat mudah terserang penyakit infeksi termasuk diare akut. 
Hasil uji statistik menunjukan ada hubungan antara status gizidengan kejadian diare pada balita di wilayah kerja Puskesmas Juntinyuat, dengan nilai $\rho$ value $=0,002$ atau nilai $\rho$ value $<0,05$. Hal ini berarti status giziberhubungan dengan kejadian diare pada balita.

Hal ini sesuai dengan penelitian Dewi (2010) yang dari hasil uji statistik didapat nilai $\mathrm{P}$ value $=0,002$ yang berarti $\mathrm{p}$ value $<\alpha(0,05)$, maka dapat diambil kesimpulan bahwa ada hubungan antara status gizi anak dengan kejadian diare. Dimana seberapa besar hubungan antara status kesehatan anak dengan kejadian diare dapat dilihat dari nilai Odd Ratioyaitu sebesar 1,970 atau bisa diartikan bahwa risiko terjadi kejadian diare (sering) pada responden dengan status gizi anak kurang 1,970 kali lebih tinggi dibandingkan responden dengan status gizi anak baik.

Penelitian ini didukung oleh penelitian yang dilakukan oleh mutia (2012) di Depok dengan sampel 95 orang bahwa ada pengaruh status gizi terhadap kejadian diare (status gizi berdasarkan PB/U OR=14,8). Penelitian lain yang dilakukan oleh Fitriyani tahun 2005 di Palembang menunjukan ada pengaruh status gizi terhadap kejadian diare. Selain itu penelitian yang dilakukan oleh Dewi tahun 2011 di Bali menunjukan ada pengaruh status gizi terhadap kejadian diare $(\mathrm{OR}=5,46, \mathrm{CI} 95 \%=3,03 \leq \mathrm{OR} \leq 9,84)$.

Status gizi merupakan faktor risiko kejadian diare akut pada anak balita. Status gizi kurang dikaitkan dengan kerentanan terhadap suatu infeksi. Nutrisi yang adekuat sangat dibutuhkan untuk berjalannya proses imunitas yang optimal dalam tubuh. Imunitas humoral dan seluler yang dominan bukan lagi memrupakan pemberian ibu, akan tetapi merupakan proses pematangan dari aspek imunologis bayi. Proses ini sangat dipengaruhi oleh status gizi anak. Proses pematangan imunitas akan berjalan dengan baik jika anak memiliki status gizi yang baik. Begitu pula sebaliknya, pada anak dengan status gizi buruk, maka perkembangan kemampuan imunitasnya juga akan terganggu.

\section{KESIMPULAN}

1) Terdapat hubungan antara pemberian ASI eksklusif dengan kejadian diare pada balita di wilayah kerja Puskesmas Juntinyuat, dengan nilai $\rho$ value $=0,001$ atau nilai $\rho$ value $<0,05$.

2) Terdapat hubungan antara status gizi dengan kejadian diare pada balita di wilayah kerja Puskesmas Juntinyuat, dengan nilai $\rho$ value $=0,002$ atau nilai $\rho$ value $<0,05$. 


\section{SARAN}

1. Bagi pihak Puskesmas, disarankan untuk melakukan peningkatan upaya penyuluhan kepada masyarakat terutama ibu tentang pentingnya upaya peningkatan gizi anak, perawatan kesehatan dan pertumbuhan anak.

2. Bagi ibu yang memiliki balita agar melakukan pemberian ASI secara eksklusif dan menjaga status gizi balita agar terhindar dari penyakit diare.

\section{UCAPAN TERIMAKASIH}

Ucapan terimakasih kepada Kepala Puskesmas Juntinyuat dan para ibu yang memiliki balita yang telah ikut berpartisipasi dalam penelitian ini.

\section{DAFTAR PUSTAKA}

Almatsier, S. (2005). Prinsip Dasar Gizi. Jakarta: Gramedia Pustaka Utama.

Arifeen, S. (2001). Exklusive Breastfeeding Reduces Acute Respiratori Infection and Diarrhea Deaths Among Infants In Dhaka Slums. Journal Of The American Academy of Pediatrics, Vol.108 No.4.

Checkley, W. (2001). Effects Of Nutritional Status On Diarrhea In Paruvian Children. Journal of Pediactrics, Vol.8:140-210.

Dewi. (2010). Hubungan Personal Hygiene dengan Terjadinya Diare pada Anak Batita di Posyandu Kelurahan Rangkapan Jaya Baru. Skripsi. Universitas Pembagunan Nasional Veteran. Depok.

Dewi, N.P.E.P. (2011). Faktor-Faktor Yang Berhubungan Dengan Kejadian Diare Pada Balita di Wilayah Puskesmas Mangwi I Kec. Mangwi Kab. Badung Propinsi Bali. Tesis. Universitas Indonesia. Depok.

Dewi, I.P. (2013). Hubungan antara Status Gizi dengan Kejadian Diare pada Balita Usia o- 60 Bulan di Posyandu Kelurahan Pendowoharjo Sewon Bantul. Yogyakarta.

Fitriyani. (2005). Hubungan Faktor-Faktor Risiko Dengan Kejadian Diare Pada Balita Di Wilayah Kerja Puskesmas Boom Baru Palembang. Skripsi. Universitas Indonesia. Jakarta.

Gibson. (2005). Status Gizi dan Pengukurannya. Institusi Pertanian Bogor.

Henny. (2014). Hubungan Pemberian ASI Eksklusif Dengan Kejadian Diare Pada Anak Usia 12-24 Bulan di Puskesmas Terjun Kec. Medan Marelan. Skripsi. Universitas Sumatra Utara. Medan.

Kementerian Kesehatan RI. (2007). Riset Kesehatan Dasar 2007. Jakarta: Badan Penelitian dan Pengembangan Kesehatan. 
Kementerian Kesehatan RI. (2011). Buletin Jendela Data dan Informasi Kesehatan: Situasi Diare Di Indonesia. Jakarta: Pusdatin, Triwulan II, 2011.

Kementrian Kesehatan RI. (2011). Buku Saku Kesehatan Petugas: Diare, Lima Langkah Tuntaskan Diare. Jakarta: Direktorat Jenderal Pengendalian Penyakit dan Penyehatan Lingkungan.

Kementerian Kesehatan RI. (2013). Riset Kesehatan Dasar 2013. Jakarta: Badan Penelitian dan Pengembangan Kesehatan.

Kementrian Kesehatan RI. (2014). Pedoman Tatalaksana Diare. Jakarta: Kementrian Kesehatan RI.

Limberti, L.M., Walker, C.L.F, Noiman, A. (2011). Breasfeeding and The Risk For Diarrhea Morbidity and Mortality. BMC Public Health. 138:297-504.

Murti, B. (1997). Prinsip dan Metode Riset Epidemiologi. Yogyakarta: Gadjah Mada University Press.

Mutia, I. (2012). Hubungan Antara Status Gizi, ASI Eksklusif, dan Faktor Lain Terhadap Frekuensi Diare Pada Anak Usia 10-23 Bulan di Puskesmas Tugu Depok. Skripsi. Jakarta: Universitas Indonesia.

Pahwa. (2010). Performance of Community-Based Health and Nutrition-education Intervention In the Management of Diarrhoe in a Slum of Delhi, India. Pumed.28(6):553-59.

Roesli, U. (2008). Inisiasi Menyusui Dini Plus ASI Eksklusif. Jakarta: Pustaka Bunda.

Sri, K. (2016). Model Prediksi Kejadian Diare Akut Pada Anak Balita Di Puskesmas Pacar Keling Kota Surabaya. Tesis. Program Studi Epidemiologi. Universitas Airlangga Surabaya.

Suhardjo. (1992). Pemberian Makanan Pada Bayi dan Anak. Yogyakarta: Kanisius.

WHO. 2013. Diarrhae Disesase. http.//www.who.int/mediacentre/factsheets/fs330/en/. Diakses Pada 01 Maret 2019.

Wijayanti, W. (2010). Hubungan antara Pemberian ASI Eksklusif dengan AngkaKejadian Diare pada Bayi Umur 0-6 Bulan di PuskesmasGilingan Kecamatan Banjarsari Surakarta.

Yurillah. (2010). Hubungan antara pemberian ASI Eksklusif dengan kejadian Diare pada bayi berusia 6-12 bulan di Kel. Bendungan Kec. Cilegon. Skripsi. Universitas Islam Negeri Syarif Hidayatullah. Jakarta. 